\title{
Enhancement of Methane Concentration by Removing Contaminants from Biogas Mixtures Using Combined Method of Absorption and Adsorption
}

\author{
Muhammad Rashed Al Mamun and Shuichi Torii \\ Department of Mechanical System Engineering, Graduate School of Science and Technology, Kumamoto University, \\ 2-39-1 Kurokami, Kumamoto 860-8555, Japan \\ Correspondence should be addressed to Muhammad Rashed Al Mamun; rashedshahi@gmail.com
}

Received 1 December 2016; Revised 31 January 2017; Accepted 5 February 2017; Published 6 March 2017

Academic Editor: Ewa Kowalska

Copyright (c) 2017 Muhammad Rashed Al Mamun and Shuichi Torii. This is an open access article distributed under the Creative Commons Attribution License, which permits unrestricted use, distribution, and reproduction in any medium, provided the original work is properly cited.

\begin{abstract}
We report a laboratory scale combined absorption and adsorption chemical process to remove contaminants from anaerobically produced biogas using cafeteria (food), vegetable, fruit, and cattle manure wastes. Iron oxide $\left(\mathrm{Fe}_{2} \mathrm{O}_{3}\right)$, zero valent iron ( $\left.\mathrm{Fe}^{\mathrm{o}}\right)$, and iron chloride $\left(\mathrm{FeCl}_{2}\right)$ react with hydrogen sulfide $\left(\mathrm{H}_{2} \mathrm{~S}\right)$ to deposit colloidal sulfur. Silica gel, sodium sulfate $\left(\mathrm{Na}_{2} \mathrm{SO}_{4}\right)$, and calcium oxide $(\mathrm{CaO})$ reduce the water vapour $\left(\mathrm{H}_{2} \mathrm{O}\right)$ and carbon dioxide $\left(\mathrm{CO}_{2}\right)$. It is possible to upgrade methane $\left(\mathrm{CH}_{4}\right)$ above $95 \%$ in biogas using chemical or physical absorption or adsorption process. The removal efficiency of $\mathrm{CO}_{2}, \mathrm{H}_{2} \mathrm{~S}$, and $\mathrm{H}_{2} \mathrm{O}$ depends on the mass of removing agent and system $\mathrm{pH}$. The results showed that $\mathrm{Ca}(\mathrm{OH})_{2}$ solutions are capable of reducing $\mathrm{CO}_{2}$ below $6 \%$. The $\mathrm{H}_{2} \mathrm{~S}$ concentration was reduced to $89 \%, 90 \%, 86 \%, 85 \%$, and $96 \%$ for treating with $10 \mathrm{~g}$ of $\mathrm{FeCl}_{2}, \mathrm{Fe}^{\mathrm{o}}$ (with $\mathrm{pH}$ ), $\mathrm{Fe}_{2} \mathrm{O}_{3}, \mathrm{Fe}^{\circ}$, and activated carbon, respectively. The $\mathrm{H}_{2} \mathrm{O}$ concentration was reduced to $0.2 \%, 0.7 \%, 0.2 \%, 0.2 \%$, and $0.3 \%$ for treating raw biogas with $10 \mathrm{~g}$ of silica gel and $\mathrm{Na}_{2} \mathrm{SO}_{4}$ for runs R1, R2, R3, R4, and R5, respectively. Thus, given the successful contaminant elimination, the combined absorption and adsorption process is a feasible system for biogas purification.
\end{abstract}

\section{Introduction}

The current use of fossil fuels is rapidly depleting the natural reserves and would be available to mankind only for a limited time due to their diversified use in every country [1]. Because of the natural formation of coal and oil however it is a very slow process which takes millions of ages to become so. Recently, sustainable solid waste management is becoming an issue of global concern due to the steady increase in population, urbanization, and industrialization. Therefore, the increasing concentration on the emission of greenhouse gases like carbon dioxide and methane having strengthened the interest for research effort is put into finding renewable fuels nowadays to replace fossil fuels $[2,3]$. Renewable fuels are in balance with the environment and contribute to a far lesser extent to the greenhouse effect. Biogas is such a renewable fuel, an energy source that can be applied to its versatility of use in gas engines, microturbines, electricity generation, and fuel cells for continuous energy production [4-8]. It is a combustible gas mixture produced by the anaerobic fermentation of biomass by bacteria and takes only a relatively short time to form. The biogas mainly consists of $60-70 \%$ combustible methane $\left(\mathrm{CH}_{4}\right)$ and $40-30 \%$ noncombustible carbon dioxide $\left(\mathrm{CO}_{2}\right)$ along with smaller amounts of other gases such as oxygen $(0-1 \%)$, nitrogen $(<1 \%)$, siloxanes $(0-$ $0.02 \%$ ), halogenated hydrocarbons (VOC, $<0.6 \%$ ), carbon monoxide (CO, $<0.6 \%)$, hydrogen sulfide $\left(\mathrm{H}_{2} \mathrm{~S}, 0.005 \%-2 \%\right)$, and water vapours $\left(\mathrm{H}_{2} \mathrm{O}, 5-10 \%\right)$ [9-13]. $\mathrm{CH}_{4}$ combusts very cleanly without any soot particles or other pollutants, making it a clean fuel. On average, the calorific value of biogas is $21.5 \mathrm{MJ} / \mathrm{m}^{3}$ whereas that of natural gas is $35.8 \mathrm{MJ} / \mathrm{m}^{3}$ [14]. The incombustible part of biogas, $\mathrm{CO}_{2}$, lowers its calorific value. By removing $\mathrm{CO}_{2}$ from the biogas the calorific value is increased. Besides $\mathrm{CO}_{2}$, biogas contains small amounts of hydrogen sulfide $\left(\mathrm{H}_{2} \mathrm{~S}\right)$. When water is present, $\mathrm{H}_{2} \mathrm{~S}$ forms sulfuric acid $\left(\mathrm{H}_{2} \mathrm{SO}_{4}\right)$, which is highly corrosive, 
rendering the biogas unusable. Currently, biogas which has been stripped of $\mathrm{H}_{2} \mathrm{~S}$ is mainly used in gas turbines to produce electricity. However, most energy is lost as heat in this process which results in a low overall efficiency. Stripping $\mathrm{CO}_{2}$ and $\mathrm{H}_{2} \mathrm{~S}$ from biogas is the so-called methane enhancing of biogas. By upgrading biogas to natural gas quality, containing more than $90 \% \mathrm{CH}_{4}$ [15], it is suitable for more advanced applications in which the heat is not wasted, resulting in a higher efficiency.

The process of enhancing biogas generates new possibilities for its use since it can then replace natural gas and be applicable for use in the vehicles. However, upgrading adds to the costs of biogas production. It is, therefore, important to have an optimized upgrading process in terms of low energy consumption and high efficiency giving high methane content in the upgraded gas. Apart from direct combustion in burners or boiler units, gas engines are usually employed as prime movers in the utilization of biogas [16-18]. There is even greater potential for biogas if it can be compressed for using in farm machinery. But all these scopes are possible only after removing $\mathrm{CO}_{2} \mathrm{H}_{2} \mathrm{~S}$ and water vapour from crude biogas. As the energy content of biogas is in direct proportion to the methane concentration, therefore, it is necessary to remove these contaminants from the raw biogas generated in the digesters to increase the energy content. Herein, we report the removal of $\mathrm{CO}_{2}, \mathrm{H}_{2} \mathrm{~S}$, and $\mathrm{H}_{2} \mathrm{O}$ from raw biogas generated from anaerobic codigestion of cattle manure (CM) with cafeteria waste $(\mathrm{CW})$, fruit waste $(\mathrm{FW})$, and vegetable waste (VW).

We used calcium oxide $(\mathrm{CaO})$, iron oxide $\left(\mathrm{Fe}_{2} \mathrm{O}_{3}\right)$, zero valent iron $\left(\mathrm{Fe}^{\mathrm{O}}\right)$, iron chloride $\left(\mathrm{FeCl}_{2}\right)$, activated carbon, silica gel, and sodium sulfate $\left(\mathrm{Na}_{2} \mathrm{SO}_{4}\right)$ for the removal of $\mathrm{CO}_{2}, \mathrm{H}_{2} \mathrm{~S}$, and $\mathrm{H}_{2} \mathrm{O}$. The effect of $\mathrm{pH}$ was observed for the purification methods. The aim of the study is to optimize the purification process in terms of saving energy consumption and high performance efficiency giving high methane concentration in the purified gas. We propose that the results of the experimental work are used in the design of a biogas treatment system especially in the farm sectors.

\section{Methods}

2.1. Anaerobic Metabolism Apparatus (Digester). A "biogas digester" is a simple system which produces usable fuel (biogas) energy, via the natural decomposition of organic material in anaerobic conditions. A laboratory scale cylindrical shape batch type digester is made of $0.2 \mathrm{~m}^{3}$ polypropylene tank (used as a reactor). The tank is airtight using rubber gasket and is clearly placed above the ground level for biogas generation. The cylindrical shape was adopted to enhance better mixing.

2.2. Preparation of Fermentation Substrates. The digestion feedstocks, namely, cafeteria waste $(\mathrm{CW})$, vegetable waste (VW), and fruit waste (FW), were collected from Kumamoto University and Kokai vegetable market, Kumamoto, Japan. The cattle manure (CM) was collected from the dairy farm, Fukuoka, Japan. Then all substrates were crushed into small pieces of $2 \mathrm{~mm}$ sizes with mechanical blender except
$\mathrm{CM}$. The blended sample was mixed with equal proportion CW : VW : FW : CM $(1: 1: 1: 1)$ and diluted with tap water in a ratio of $1: 1$. The prepared feedstock was fed by a volume of $0.16 \mathrm{~m}^{3}$ in the biogas digester.

2.3. Absorption and Adsorption Materials. In the laboratory study, all chemicals were reagent grade or above and used without further purification. The purification materials were used divided into five different mixtures shown in Table 1. All purification reagents were derived from Kanto Chemical Co., Ltd., Japan. Calcium oxide $(\mathrm{CaO})$ and silica gel were crushed manually into powder form to increase the internal surface area.

2.4. Procedure of the Experiment. The experiments have been carried out in laboratory scale set-up schematically as shown in Figure 1. The set-up consists of three sections: a metabolism section to generate the desired biogas, a contaminants removal section to purify the biogas, and an analysis section. During the study, the experiment was operated batchwise with respect to absorption and adsorption phase. The first section (1) is digester as previously described. The second (2) section is raw gas collection chamber, purification, and the raw biogas sampling section. And the third (3) section is the purified biogas sampling bag. The purification unit consists of three glass flasks $\left(0.002 \mathrm{~m}^{3}\right)$. We also changed $\mathrm{CaO}$ to $\mathrm{Ca}(\mathrm{OH})_{2}$ to obtain positive results. The first flask contains $\mathrm{Ca}(\mathrm{OH})_{2}$ solution which was varied from 1 to $10 \mathrm{~g}$ per liter of water for all the experimental runs. The raw gas collection flask and first purification flask were interconnected by $5 \mathrm{~mm}$ diameter $0.4 \mathrm{~m}$ long hose pipe. Under batch mode conditions, the raw biogas is introduced by $5 \mathrm{~mm}$ in diameter, $0.3 \mathrm{~m}$ long glass tubing at $0.3 \mathrm{~mm}$ above from the bottom of the absorber flask as small bubbles through the $\mathrm{Ca}(\mathrm{OH})_{2}$ $\mathrm{Ca}(\mathrm{OH})_{2}$ solution to remove $\mathrm{CO}_{2}$, in all runs.

For the adsorption of contaminants $\left(\mathrm{H}_{2} \mathrm{~S}\right.$ and $\left.\mathrm{H}_{2} \mathrm{O}\right)$, the first, second, and third removal flask was interconnected by $5 \mathrm{~mm}$ diameter and $1 \mathrm{~m}$ long $\mathrm{U}$-shaped hose pipe. For the absorption of $\mathrm{H}_{2} \mathrm{~S}$, the first and second were interconnected by $5 \mathrm{~mm}$ diameter hose pipe on the top of the flasks along two $5 \mathrm{~mm}$ in diameter, $0.3 \mathrm{~m}$ long glass tubing at $0.3 \mathrm{~mm}$ above from the bottom of the $\mathrm{H}_{2} \mathrm{~S}$ absorption flask as small bubbles through the $\mathrm{H}_{2} \mathrm{~S}$ removal solutions, in runs R1, R2, R3, and R4, respectively. On the other hand, removal of $\mathrm{H}_{2} \mathrm{~S}$ hose pipe was filled with activated carbon and for run 5 (R5). The contaminate biogas enters the $\mathrm{H}_{2} \mathrm{~S}$ adsorption column after passing the $\mathrm{CO}_{2}$ capture trap through the activated carbon to remove $\mathrm{H}_{2} \mathrm{~S}$. Herein notice that when gas was transferred from $\mathrm{CO}_{2}$ flask to $\mathrm{H}_{2} \mathrm{~S}$ removal flask, the first and second flask $\mathrm{U}$-shaped connected line was closed by using gas flow control valve in runs R1, R2, R3, and R4 and vice versa for run 5 , the glass tubing line was closed.

Similarly, the removal of $\mathrm{H}_{2} \mathrm{O}$ the $\mathrm{U}$-shaped adsorption hose column was filled with a freshly prepared powder and granular form of silica gel and sodium sulfate for runs R1, $\mathrm{R} 3$ and R4, and R2 and R5, respectively. The biogas enters the moisture eliminate column after passing the $\mathrm{H}_{2} \mathrm{~S}$ removal unit to ensure that the biogas was dry. As silica gel, $\mathrm{Na}_{2} \mathrm{SO}_{4}$, and activated carbon materials have significant water and $\mathrm{H}_{2} \mathrm{~S}$ 


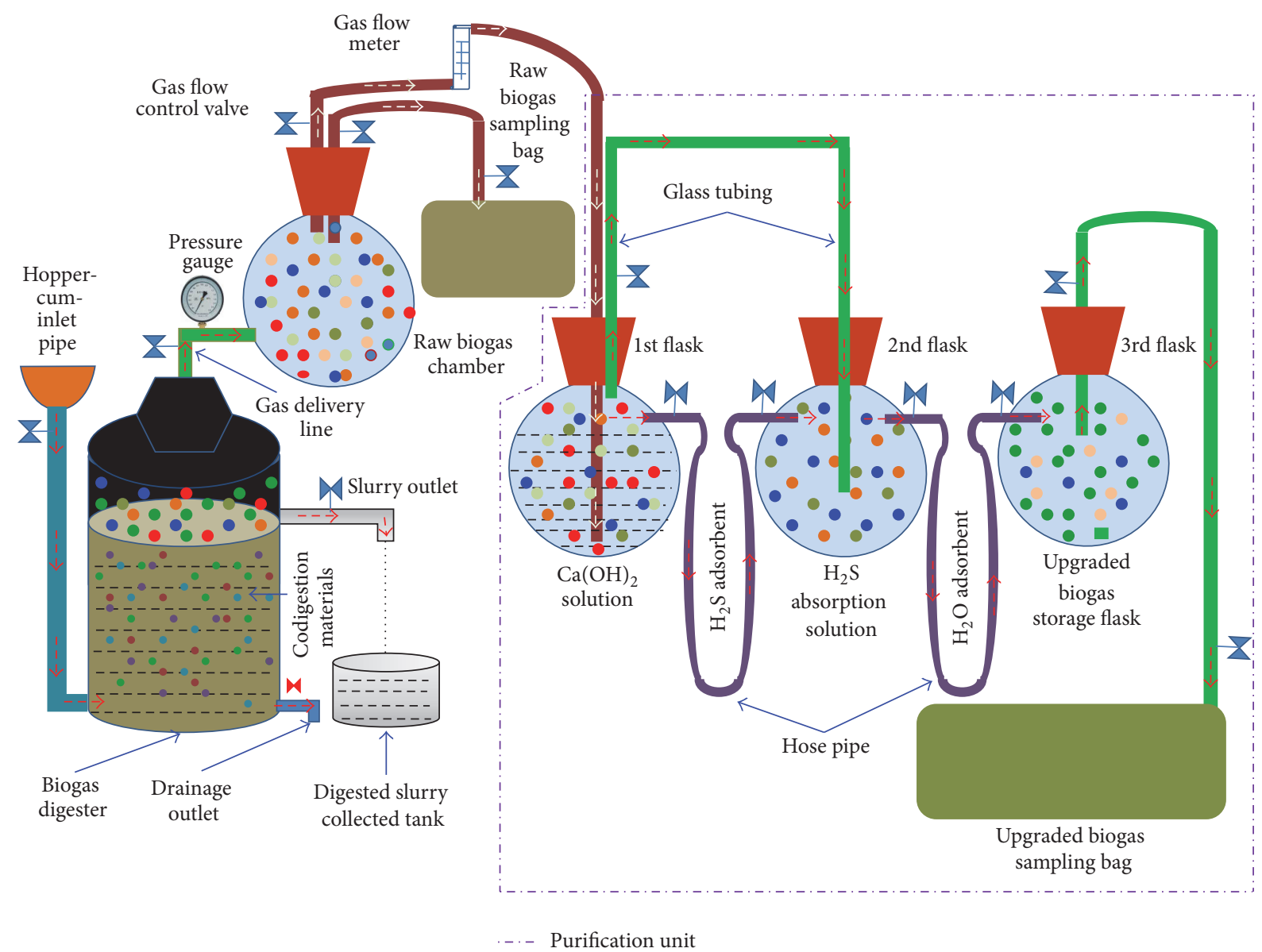

FIGURE 1: Schematic of experimental apparatus set-up for purification of biogas.

TABLE 1: Experimental properties of methane enhancement research work.

\begin{tabular}{|c|c|c|c|c|c|c|}
\hline Run & Removal mixture & Uploaded water (l) & Chemical substances quantity (g) & Range of $\mathrm{pH}$ & pH modulates & Time per exp. (Min.) \\
\hline & $\mathrm{CaO}$ & 1 & & - & & \\
\hline \multirow[t]{3}{*}{$\mathrm{R} 1$} & $\mathrm{Fe}_{2} \mathrm{O}_{3}$ & 1 & $1-10$ & $5-9.5$ & $\mathrm{HCl} / \mathrm{NH}_{3}$ & 60 \\
\hline & Silica gel & - & & - & & \\
\hline & $\mathrm{CaO}$ & 1 & & - & & \\
\hline \multirow[t]{3}{*}{ R2 } & $\mathrm{Fe}^{\mathrm{o}}$ & 1 & $1-10$ & $5-9.5$ & $\mathrm{HCl} / \mathrm{NH}_{3}$ & 60 \\
\hline & $\mathrm{Na}_{2} \mathrm{SO}_{4}$ & - & & - & & \\
\hline & $\mathrm{CaO}$ & 1 & & - & & \\
\hline \multirow[t]{3}{*}{ R3 } & $\mathrm{FeCl}_{2}$ & 1 & $1-10$ & $5-9.5$ & $\mathrm{HCl} / \mathrm{NH}_{3}$ & 60 \\
\hline & Silica gel & - & & - & & \\
\hline & $\mathrm{CaO}$ & 1 & & - & & \\
\hline \multirow[t]{3}{*}{$\mathrm{R} 4$} & $\mathrm{Fe}^{\mathrm{o}}$ & 1 & $1-10$ & - & - & 60 \\
\hline & Silica gel & - & & 一 & & \\
\hline & $\mathrm{CaO}$ & 1 & & - & & \\
\hline \multirow[t]{2}{*}{ R5 } & Activated carbon & - & $1-10$ & - & - & 60 \\
\hline & $\mathrm{Na}_{2} \mathrm{SO}_{4}$ & - & & - & & \\
\hline
\end{tabular}

adsorbing capability, therefore, biogas flows through these adsorbents from the one end to the other end of the hose. In this regard, both ends of the hose pipe column were attached by soft cotton to increase adsorbing ability. At the end of experiment, purified methane-rich biogas comes out on the top of the flask with $\mathrm{CO}_{2}, \mathrm{H}_{2} \mathrm{~S}$, and $\mathrm{H}_{2} \mathrm{O}$ being stripped off. Then the purified gas is accumulated in a $0.05 \mathrm{~m}^{3}$ aluminum gas sampling bag for analyzing gas compositions. Biogas samples were collected before and after it flowed through these media and $\mathrm{CH}_{4}$ enriched content and the capturing 
efficiency was investigated as the percentage of $\mathrm{CO}_{2}, \mathrm{H}_{2} \mathrm{~S}$, and $\mathrm{H}_{2} \mathrm{O}$ removed from the biogas of each sample. The design consideration was that there were to be no energy requirements for the system operation.

2.5. Sample Measurement Methods. Gas composition was analyzed off line by gas chromatography (GC-8AIT/C159 R8A SHIMADZU Corporation, Japan) and Testo-350 portable gas analyzer (Testo AG, Germany). The gas chromatograph (GC) was fitted with a Porapak N 80/100, $274.32 \mathrm{~cm}$, $1 / 8$ mesh $250 \times 250 \times 145 \mathrm{~mm}$ column, a molecular sieve (mole sieve 5A 60/80, $182.88 \mathrm{~cm}, 1 / 8$ ), maximum temperature $399^{\circ} \mathrm{C}$, temperature stability $\pm 0.1^{\circ} \mathrm{C}$ a stainless-steel column, and a thermal conductivity detector. Detector type was TCD made by tungsten rhenium filament. Maximum temperature and sensitivity of the detector were $400^{\circ} \mathrm{C}$ and $7000(\mathrm{mVmL} / \mathrm{mg})$, respectively. Argon (Ar) was used as the carrier gas at a flow rate of $30 \mathrm{~mL} / \mathrm{min}$. The column temperature was $60^{\circ} \mathrm{C}$ and the injector/detector temperatures were $80^{\circ} \mathrm{C}$ and current $60(\mathrm{~mA})$. Methane, $\mathrm{CO}_{2}, \mathrm{H}_{2} \mathrm{~S}$, and $\mathrm{H}_{2} \mathrm{O}$ content of raw biogas and purified biogas were analyzed and compared. The rate of gas flow, pressure, $\mathrm{pH}$, and water content were measured using gas flow meter, pressure gauge, digital $\mathrm{pH}$ meter (HM-25R), and moisture meter (MOC63u), respectively.

\section{Results and Discussion}

3.1. Absorption of $\mathrm{CO}_{2}$. It refers to the process by which one element, such as a solid or liquid, takes up another element, such as a liquid or gas, through minute pores or spaces between its molecules. The absorption capability of the absorber depends on the equilibrium concentrations between liquid phase and gaseous phase. In this study, $\mathrm{CaO}$ solution was used as a chemical solvent to demonstrate the ability to absorb $\mathrm{CO}_{2}$ from the gas stream. It is an effective method to remove $\mathrm{H}_{2} \mathrm{~S}$ along with $\mathrm{CO}_{2}$ from biogas. The calcium oxide (slaked lime) solution is used to promote the chemical reactions:

$$
\begin{aligned}
\mathrm{CO}_{2(\mathrm{~g})}+\mathrm{H}_{2} \mathrm{O}_{(\mathrm{l})} & \longrightarrow \mathrm{H}_{2} \mathrm{CO}_{3(\mathrm{aq})} \\
\mathrm{CaO}_{(\mathrm{s})}+\mathrm{H}_{2} \mathrm{CO}_{3(\mathrm{aq})} & \longrightarrow \mathrm{CaCO}_{3(\mathrm{~s})}+\mathrm{H}_{2} \mathrm{O}_{(\mathrm{l})} \\
\mathrm{CaO}+\mathrm{H}_{2} \mathrm{O} & \longrightarrow \mathrm{Ca}(\mathrm{OH})_{2(\mathrm{aq})} \\
\mathrm{Ca}(\mathrm{OH})_{2(\mathrm{aq})}+\mathrm{H}_{2} \mathrm{CO}_{3(\mathrm{aq})} & \longrightarrow \mathrm{CaCO}_{3(\mathrm{~s})}+\mathrm{H}_{2} \mathrm{O}_{(\mathrm{l})}
\end{aligned}
$$

Figure 2 shows the inflow versus outflow $\mathrm{CO}_{2}$-concentration of biogas for all experiments after treating with 1$10 \mathrm{~g}$ of $\mathrm{CaO}$ solution. During the experimentation phase, the $\mathrm{CO}_{2}$-concentration of the biogas inflow varied from a minimum of $33 \%, 34 \%, 36 \%, 35 \%$, and $34 \%$ to $37 \%, 38 \%, 40 \%$, $40 \%$, and $38 \%$ for the runs R1, R2, R3, R4, and R5, respectively. The $\mathrm{CO}_{2}$-concentration of biogas decreased from approximately $25 \%, 28 \%, 29 \%, 26 \%$, and $24 \%$ to $5 \%, 5.8 \%, 5.8 \%$, $5.9 \%$, and $3 \%$ at 1 to $10 \mathrm{~g}$ of $\mathrm{CaO}$ in $\mathrm{R} 1, \mathrm{R} 2, \mathrm{R} 3, \mathrm{R} 4$, and $\mathrm{R} 5$, respectively. We observed that the run (R5) of $\mathrm{CO}_{2}$ concentration decreased significantly higher than other runs. It is because $\mathrm{CO}_{2}$ is also absorbed when passing through the

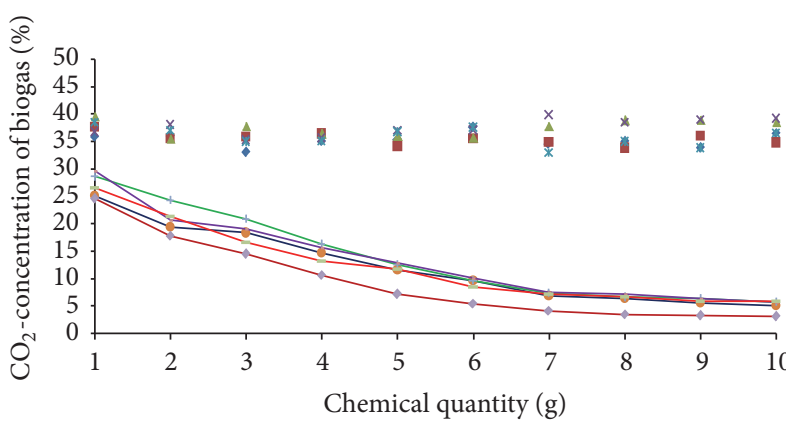

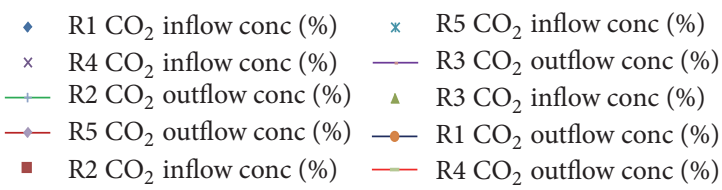

FIGURE 2: $\mathrm{CO}_{2}$ inflow versus outflow concentration of biogas under the treatments of runs R1, R2, R3, R4, and R5.

activated carbon and silica gel during the study. It is noticeable that the concentration of $\mathrm{CO}_{2}$ decreased sharply in all experiments up to $6 \mathrm{~g}$ of $\mathrm{CaO}$ solution and the decreasing trends almost remained stable at 7 to $10 \mathrm{~g}$.

3.2. Absorption and Adsorption of Hydrogen Sulfide $\left(\mathrm{H}_{2} \mathrm{~S}\right)$. To characterize the chemical reagents some experiments were performed using the absorption of $\mathrm{H}_{2} \mathrm{~S}$ in an $\mathrm{Fe}_{2} \mathrm{O}_{3} / \mathrm{Fe}^{\mathrm{o}} / \mathrm{FeCl}_{2}$ solution. The $\mathrm{pH}$ value of the phase was modulated by $\mathrm{HCl}$ and $\mathrm{NH}_{3}$ solution for runs $\mathrm{R} 1, \mathrm{R} 2$, and $\mathrm{R} 3$. The $\mathrm{NH}_{3}$ solution was chosen because the reaction of $\mathrm{H}_{2} \mathrm{~S}$ and $\mathrm{NH}_{4} \mathrm{OH}$ solution is instantaneous with respect to mass transfer and the absorption of $\mathrm{H}_{2} \mathrm{~S}$ is therefore gas phase mass transfer controlled if the concentration of the $\mathrm{NH}_{3}$ concentration is sufficiently high [19]. The experimental data are presented in Figure 3(a). From Figure 3(a) it can be seen that, at a $\mathrm{pH}$ higher than 9 , the conversion of $\mathrm{H}_{2} \mathrm{~S}$ was more or less independent of the $\mathrm{pH}$ and the initial concentration of $\mathrm{H}_{2} \mathrm{~S}$ in the gas. When the $\mathrm{pH}$ dropped below 7 the removal of $\mathrm{H}_{2} \mathrm{~S}$ concentration decreased significantly in $\mathrm{R} 1$ and $\mathrm{R} 3$. The absorption of $\mathrm{H}_{2} \mathrm{~S}$ in $\mathrm{Fe}_{2} \mathrm{O}_{3} / \mathrm{FeCl}_{2}$ solutions has been studied as a function of the $\mathrm{pH}$ of the solution and the concentration of $\mathrm{H}_{2} \mathrm{~S}$ in the gas entering the reactor. At the start of an experiment, the $\mathrm{pH}$ was brought to a value of approximately 5 by adding some $\mathrm{HCl}$. At a $\mathrm{pH}$ of approximately 5 , the $\mathrm{H}_{2} \mathrm{~S}$ uptake of the solution decreased slightly and a small amount of $\mathrm{NH}_{3}$ was added to bring the $\mathrm{pH}$ of the solution 0.5 intervals from 5 to 9.5. Then a gas stream with a different concentration of $\mathrm{H}_{2} \mathrm{~S}$ was brought in contact with the solution and the experiment was continued. Using this procedure the average concentration of $\mathrm{H}_{2} \mathrm{~S}$ in the gas entering the reactor was varied between $478 \mathrm{ppm}$ and $492 \mathrm{ppm}$ and $480 \mathrm{ppm}$ and 512 ppm for R1 and R3, respectively. From the experimental results obtained with the solutions it can be concluded that it is possible to decrease $50 \mathrm{ppm}$ and $69 \mathrm{ppm}$ of the $\mathrm{H}_{2} \mathrm{~S}$ from a gas stream that initially contains between $478 \mathrm{ppm}$ and $492 \mathrm{ppm}$ and $480 \mathrm{ppm}$ and $512 \mathrm{ppm}_{2} \mathrm{~S}$ for R1 and R3 respectively, when the $\mathrm{pH}$ of the solution is 9.5. With the $\mathrm{pH}$ below 7 the removal of $\mathrm{H}_{2} \mathrm{~S}$ appeared to be lower. This might 


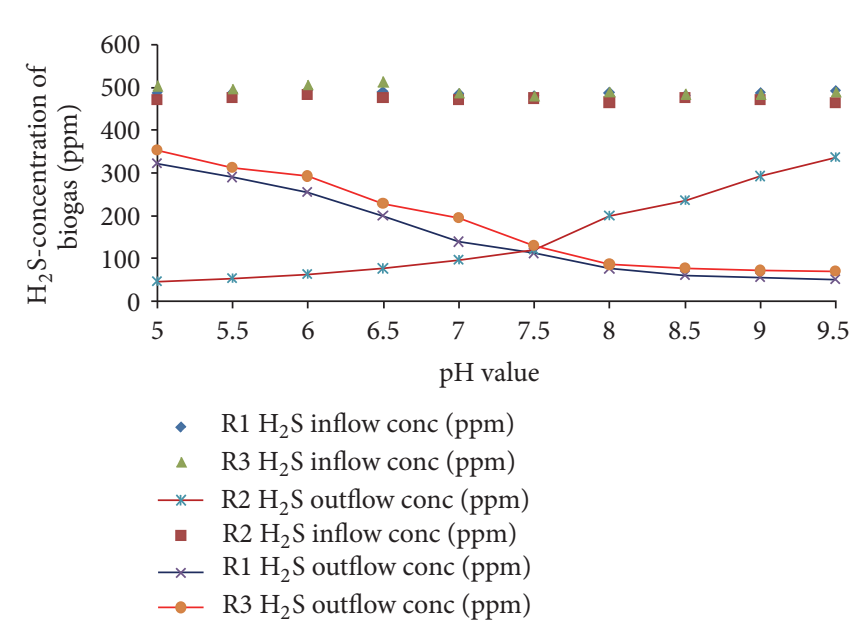

(a)

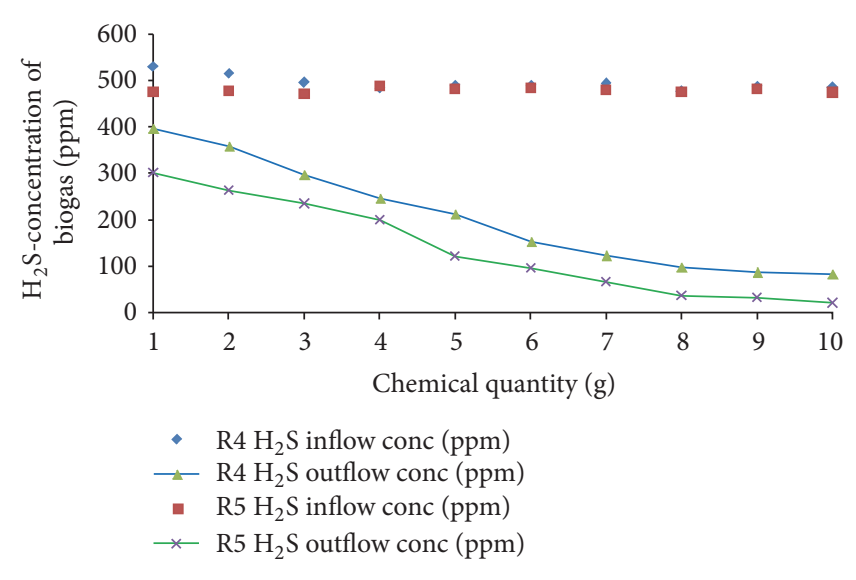

(b)

FIgURE 3: (a) $\mathrm{H}_{2} \mathrm{~S}$ inflow versus outflow concentration of biogas under the treatments of runs R1, R2, and R3 and (b) for runs R4 and R5.

be caused that the absorption of $\mathrm{H}_{2} \mathrm{~S}$ was not (completely) gas phase mass transfer limited but also partly influenced by precipitation and/or liquid phase mass transfer. However, the results show that a virtually low desulfurization should be possible at $\mathrm{pH}$ values as low as 5.5. The chemical reactions that take place with the $\mathrm{H}_{2} \mathrm{~S}, \mathrm{FeCl}_{2}$, and $\mathrm{Fe}_{2} \mathrm{O}_{3}$ are as follows:

$$
\begin{gathered}
\mathrm{FeCl}_{2}+\mathrm{H}_{2} \mathrm{~S} \longrightarrow \mathrm{FeS} \downarrow+2 \mathrm{HCl} \\
2 \mathrm{Fe}_{2} \mathrm{O}_{3(\mathrm{~s})}+6 \mathrm{H}_{2} \mathrm{~S}_{(\mathrm{g})} \longrightarrow 2 \mathrm{Fe}_{2} \mathrm{~S}_{3(\mathrm{~s})}+6 \mathrm{H}_{2} \mathrm{O}
\end{gathered}
$$

The reaction is slightly endothermic: a temperature minimum of about $12^{\circ} \mathrm{C}$ is required to provide the necessary energy. The iron oxide can be regenerated with oxygen according to the following reaction:

$$
2 \mathrm{Fe}_{2} \mathrm{~S}_{3}+3 \mathrm{O}_{2} \longrightarrow 2 \mathrm{Fe}_{2} \mathrm{O}_{3}+6 \mathrm{~S}
$$

This reaction is exothermic and therefore a large amount of heat is released during regeneration process [15].

On the other hand, for $\mathrm{R} 2, \mathrm{Fe}^{\mathrm{o}}$ represented a nanotechnology material providing high surface areas, developing a nanoscale absorbent with high absorption capacity becoming promising for $\mathrm{H}_{2} \mathrm{~S}$ removal $[20,21]$. Herein we investigated the effectiveness of $\mathrm{Fe}^{\mathrm{o}}$ for sulfide removal with respect to $\mathrm{pH}$ conditions range which varied 5-9.5 illustrated in Figure 3(a). From R2, it can be seen that, at a pH higher than 9, the conversion of $\mathrm{H}_{2} \mathrm{~S}$ was less which are reversed behavior compared to $\mathrm{R} 1$ and $\mathrm{R} 3$. The average sulfide concentration was passed about $471 \mathrm{ppm}$ through $\mathrm{Fe}^{\mathrm{o}}$ solution. Approximately $426 \mathrm{ppm}$ of sulfide concentration was removed at $\mathrm{pH} 5$ in $\mathrm{R} 2$ and comes to $45 \mathrm{ppm}$. However, the sulfide removal concentration decreased as $\mathrm{pH}$ increased. In this study, we observed that the oxidation of $\mathrm{Fe}^{\mathrm{O}}$ leading to the generation of $\mathrm{Fe}(\mathrm{II})$ is favorable under acidic conditions:

$$
\mathrm{Fe}_{(\mathrm{s})}^{\mathrm{o}}+2 \mathrm{H}_{2} \mathrm{O} \longrightarrow \mathrm{Fe}^{2+}+\mathrm{H}_{2(\mathrm{~g})}+2 \mathrm{OH}^{-}
$$

Sulfide readily reacted with $\mathrm{Fe}(\mathrm{II})$ to form iron sulfide (FeS) $[22,23]$ :

$$
\begin{aligned}
& \mathrm{Fe}^{2+}+\mathrm{H}_{2} \mathrm{~S} \longrightarrow \mathrm{FeS}+2 \mathrm{H}^{+} \\
& \mathrm{Fe}^{2+}+\mathrm{HS}^{-} \longrightarrow \mathrm{FeS}+\mathrm{H}^{+}
\end{aligned}
$$

Accordingly, the $\mathrm{pH}$ effect on the sulfide removal with $\mathrm{Fe}^{\mathrm{O}}$ may be attributed to the formation of FeS through the precipitation of $\mathrm{Fe}$ (II) and sulfide.

Similarly, for an aqueous $\mathrm{Fe}^{\mathrm{o}}$ solution the $\mathrm{H}_{2} \mathrm{~S}$ conversion was also measured for various inflow $\mathrm{H}_{2} \mathrm{~S}$ concentrations and as a function of the mass in the solution as shown in Figure 3(b). The quantity of $\mathrm{Fe}^{\mathrm{o}}$ increased gradually in the solution up to $10 \mathrm{~g}$. At $10 \mathrm{~g}$ the $\mathrm{H}_{2} \mathrm{~S}$ concentration became lower than $85 \mathrm{ppm}$ and the experiment was stopped. A number of experiments were performed with $\mathrm{H}_{2} \mathrm{~S}$ concentrations in the gas entering the reactor varying between $475 \mathrm{ppm}$ and $530 \mathrm{ppm}$ for run R4. When the experimental results are compared, it can be seen that aqueous $\mathrm{Fe}^{\mathrm{o}}$ solutions behave slightly lower than $\mathrm{Fe}^{\mathrm{o}}$ solutions with $\mathrm{pH}$ study with respect to the absorption of $\mathrm{H}_{2} \mathrm{~S}$. However, it appeared, for example, to be possible to remove more than $412 \mathrm{ppm}$ of $\mathrm{H}_{2} \mathrm{~S}$ from a gas stream that on average contained $494 \mathrm{ppm}$ of $\mathrm{H}_{2} \mathrm{~S}$ at $10 \mathrm{~g}$ of $\mathrm{Fe}^{\mathrm{o}}$. It can be seen that a substantial decreasing trend remained almost stable in $\mathrm{H}_{2} \mathrm{~S}$ concentration, between the quantities 8 to $10 \mathrm{~g}$.

Finally, the selected activated carbon was tested along with the variable mass of $\mathrm{H}_{2} \mathrm{~S}$ removing phase (activated carbon). As shown in Figure 3(b), the average $\mathrm{H}_{2} \mathrm{~S}$-concentration was varied $473 \mathrm{ppm}$ and $487 \mathrm{ppm}$ introduced into the run (R5); after adsorption, this concentration gradually decreased based on the amount by up to $20 \mathrm{ppm}$ when $10 \mathrm{~g}$ activated carbon is used.

The $\mathrm{H}_{2} \mathrm{~S}$-concentration was changed from $301 \mathrm{ppm}$ to $20 \mathrm{ppm}$ at 1 and $10 \mathrm{~g}$ activated carbon, respectively. We observed that the adsorbing capacities depend on the degree of saturation and the mass of adsorbing substance. In this case, the activated carbon removed more $\mathrm{H}_{2} \mathrm{~S}$ than other runs 
due to its extremely porous form of carbon and thus it has a very large surface area available for adsorption [24]. It also shows strong affinity to polar substances such as $\mathrm{H}_{2} \mathrm{O}, \mathrm{H}_{2} \mathrm{~S}$, $\mathrm{CO}_{2}$, and $\mathrm{SO}_{2}$. In this case of $\mathrm{H}_{2} \mathrm{~S}$, activated carbon adsorbs and decomposes it to elemental sulfur.

3.3. Adsorption of Water Vapour $\left(\mathrm{H}_{2} \mathrm{O}\right)$. It refers to the process by which molecules of a substance, such as a gas or a liquid, collect on the surface of a solid. The objective of this experiment was to investigate that $\mathrm{H}_{2} \mathrm{O}$ can be efficiently removed from a biogas stream. Because biogas from digesters is normally collected from headspace above a liquid surface or very moist substrate, the gas is usually saturated with water stream. The amount of saturated water vapour in a gas depends on temperature and pressure. Biogas typically contains $10 \%$ water vapour by volume at $43^{\circ} \mathrm{C}, 5 \%$ by volume at $32^{\circ} \mathrm{C}$, and $1 \%$ by volume at $4.5^{\circ} \mathrm{C}$ [25]. The removal of water vapour (moisture) from biogas reduces corrosion that results when the $\mathrm{H}_{2} \mathrm{~S}$ and $\mathrm{CO}_{2}$ have not been removed from the biogas because the $\mathrm{H}_{2} \mathrm{~S}$ and $\mathrm{CO}_{2}$ and water vapour react to form different acids, which can result in a severe risk factor in equipment that comes into contact with the biogas. In addition, water vapour condenses within a system due to pressure or temperature changes; it can result in clogging of the pipes. The adsorption process was carried out at different mass of adsorbent substances in the range from 1 to $10 \mathrm{~g}$. Figure 4 represents the change in $\mathrm{H}_{2} \mathrm{O}$-concentration in raw and purified biogas for the all experimental runs. During the operation the concentration of $\mathrm{H}_{2} \mathrm{O}$ of the gas was monitored entering and leaving the reactor. When the mass of silica gel is $1 \mathrm{~g}$ the removal media were capable of decreasing the $\mathrm{H}_{2} \mathrm{O}$ concentration in the gas with approximately $1.7 \%, 1.6 \%$, and $1.5 \%$ in runs $\mathrm{R} 1, \mathrm{R} 3$, and $\mathrm{R} 4$, respectively. When the silica gel quantity of the removing reactor increased until $10 \mathrm{~g}$, the degree of removal increased considerably. The colour of the silica gel was changed from blue to pink after absorbing water vapour from the raw biogas. The reason is that silica gel is extremely porous and can adsorb a large amount of water due to its large internal surface area. However, the $\mathrm{H}_{2} \mathrm{O}$-concentration in the purified biogas at the end of the experiment was contained $0.25 \%, 0.24 \%$, and $0.21 \%$ for runs $\mathrm{R} 1, \mathrm{R} 3$, and R4, respectively. The results show that the removal of $\mathrm{H}_{2} \mathrm{O}$-concentration almost remained stable at 8 to $10 \mathrm{~g}$ of silica gel. The silica gel was reactivated after saturation by heating it in an oven at $150^{\circ} \mathrm{C}$ for 3 hours to remove the adsorbed $\mathrm{H}_{2} \mathrm{O}$.

To demonstrate the adsorption of $\mathrm{H}_{2} \mathrm{O}$ from biogas by treating $\mathrm{Na}_{2} \mathrm{SO}_{4}$ substance on lab scale reactor plants, Figure 4 represents also the removal of $\mathrm{H}_{2} \mathrm{O}$ of the biogas entering and leaving the reactor which was investigated using $\mathrm{Na}_{2} \mathrm{SO}_{4}$ as an adsorbent. From this figure, it can be seen that when the $\mathrm{Na}_{2} \mathrm{SO}_{4}$ quantity in the adsorption column is significantly high $(10 \mathrm{~g})$, the $\mathrm{Na}_{2} \mathrm{SO}_{4}$ substance is capable of decreasing the $\mathrm{H}_{2} \mathrm{O}$ concentration in the gas by approximately $4 \%$ and $5.5 \%$ from $4.8 \%$ and $5.9 \%$ in runs R2 and R5, respectively. The results showed that the concentration of $\mathrm{H}_{2} \mathrm{O}$ in the biogas stream leaving the adsorber was approximately $0.7 \%$ and $0.3 \%$ at $10 \mathrm{~g}$ of $\mathrm{Na}_{2} \mathrm{SO}_{4}$ in runs $\mathrm{R} 2$ and $\mathrm{R} 5$, respectively. It can be seen that the run R2

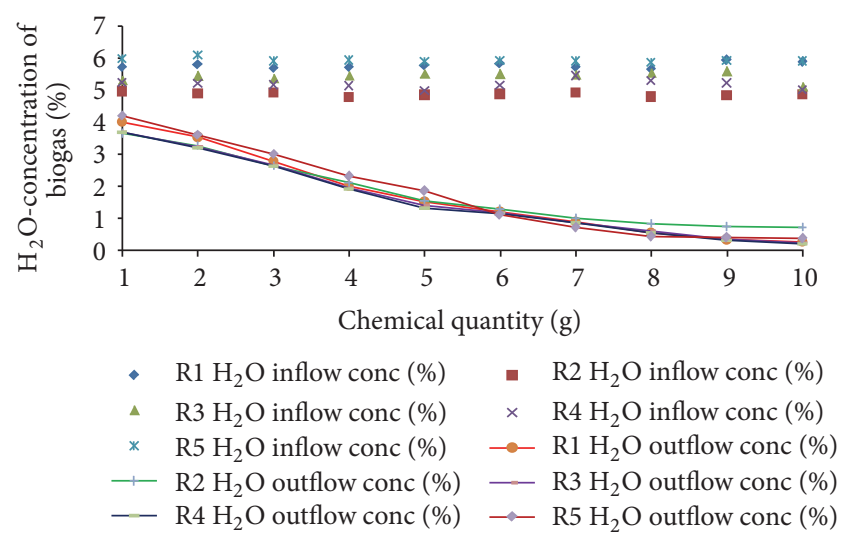

FIGURE 4: $\mathrm{H}_{2} \mathrm{O}$ inflow versus outflow concentration of biogas under the treatments of runs R1, R2, R3, R4, and R5.

adsorption capacity is significantly lower than R5. The exact reason is that in $\mathrm{R} 5$ the activated carbon also adsorbed some water molecules before entering moisture trapped column of $\mathrm{Na}_{2} \mathrm{SO}_{4}$. We also investigated the $\mathrm{H}_{2} \mathrm{O}$ concentration that remained almost stable at 8 to $10 \mathrm{~g}$ of $\mathrm{Na}_{2} \mathrm{SO}_{4}$ and then the experiment was stopped.

3.4. Comparative Removal Efficiency of the Study Runs R1, $R 2$, and $R 3$. Figure 5(a) shows the results obtained in terms of $\mathrm{CO}_{2}, \mathrm{H}_{2} \mathrm{~S}$, and $\mathrm{H}_{2} \mathrm{O}$ removing efficiencies as function of mass and $\mathrm{pH}$. First, we made a comparative analysis of the different research stages. It shows the different types of removal substances for runs R1 and R3 with almost similar results of $\mathrm{CO}_{2}$ and $\mathrm{H}_{2} \mathrm{O}$ removing phase, whereas $\mathrm{R} 1$ and $\mathrm{R} 2$ present similar results of $\mathrm{H}_{2} \mathrm{~S}$ removing phase. But for a run (R2) maximum removal efficiency was observed at low $\mathrm{pH}$, whereas $\mathrm{R} 1$ maximum efficiency was obtained at high $\mathrm{pH}$. The reason is that the oxidation of $\mathrm{Fe}^{\mathrm{o}}$ leading to generation of $\mathrm{Fe}(\mathrm{II})$ is favorable under acidic conditions and $\mathrm{Fe}_{2} \mathrm{O}_{3}$ favorable under base conditions In case of R1 and R3 results showed that the $\mathrm{CO}_{2}$ and $\mathrm{H}_{2} \mathrm{O}$ removal efficiency was similar due to the same material used. However, the R1, R2, and $\mathrm{R} 3$ are able to reach $\mathrm{H}_{2} \mathrm{~S}>89 \%, 90 \%$, and $85 \%$ (final $\mathrm{H}_{2} \mathrm{~S}$ $=50 \mathrm{ppm}, 45 \mathrm{ppm}$, and $69 \mathrm{ppm}$ ) for $10 \mathrm{~g}$ when $\mathrm{pH}=9.5,5$, and 9.5. Under these circumstances removal efficiency of $\mathrm{CO}_{2}>$ $85 \%, 83 \%$, and $84 \%$ (final $\mathrm{CO}_{2}<6 \%$ ) and $\mathrm{H}_{2} \mathrm{O}>95 \%, 85 \%$, $95 \%$ (final $\mathrm{CO}_{2}<0.2 \%, 0.7 \%$, and $0.2 \%$ ) for $10 \mathrm{~g}$, respectively. It can be seen that the removal efficiency of $\mathrm{H}_{2} \mathrm{O}$ for $\mathrm{R} 2$ is a little bit lower due to hard granular form $\left(\mathrm{Na}_{2} \mathrm{SO}_{4}\right)$ results that lower adsorption capacity. This result shows that the best removal efficiency was achieved in $\mathrm{R} 1$, although there were not so significant differences of performance compared with other contaminants elimination methods.

3.5. Comparative Removal Efficiency of the Study between Runs R4 and R5. The contaminants of biogas removal efficiency for runs R4 and R5 increased during the experimental period as shown in Figure 5(b). The results showed that the most efficient performance in $\mathrm{R} 5$ was investigated to compare between runs R4 and R5. The operation of the system in runs R4 and R5 was very similar with slightly better results in run 


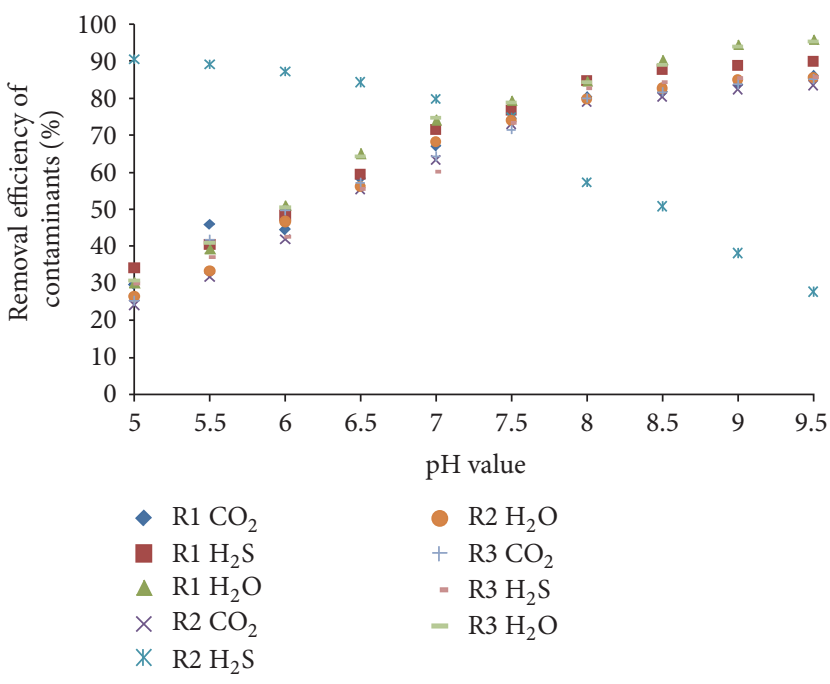

(a)

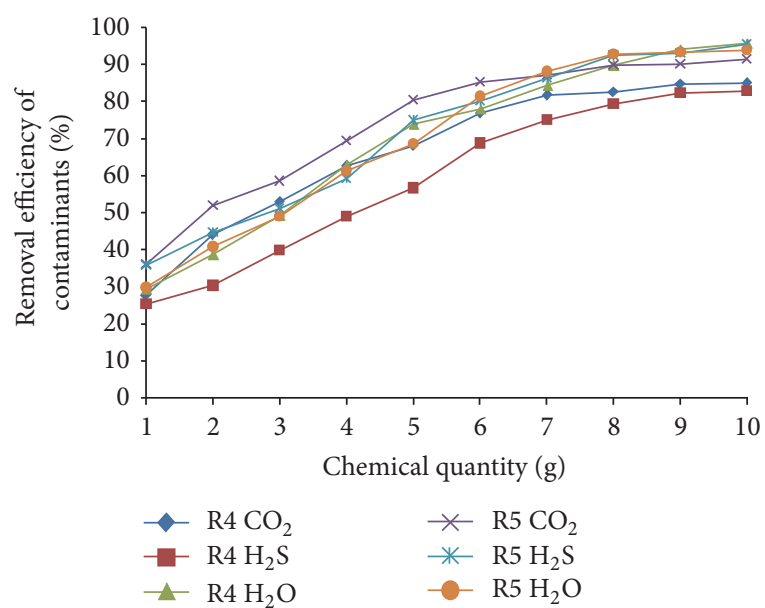

(b)

FiguRE 5: (a) $\mathrm{CO}_{2}, \mathrm{H}_{2}$ S, and $\mathrm{H}_{2} \mathrm{O}$ removal efficiency of biogas under the treatments of runs R1, R2, and R3 and (b) for runs R4 and R5.

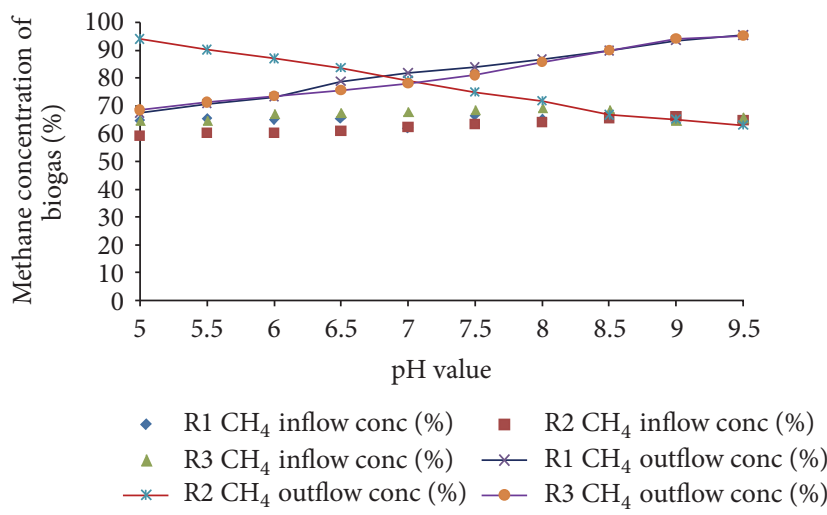

(a)

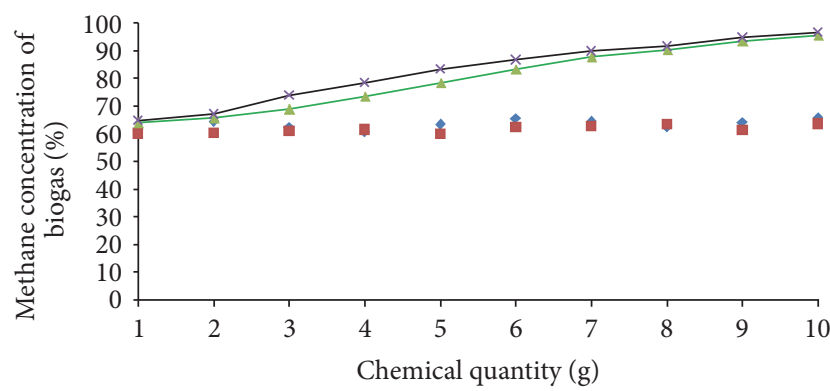

- $\mathrm{R} 4 \mathrm{CH}_{4}$ inflow conc (\%) - $\mathrm{R}_{5} \mathrm{CH}_{4}$ inflow conc (\%)

$\rightarrow \mathrm{R} 4 \mathrm{CH}_{4}$ outflow conc (\%) $\rightarrow-\mathrm{R}_{5} \mathrm{CH}_{4}$ outflow conc (\%)

(b)

FIGURE 6: (a) $\mathrm{CH}_{4}$ inflow versus outflow concentration of biogas under the treatments of runs R1, R2, and R3 and (b) for runs R4 and R5.

$\mathrm{R} 5$ with respect to $\mathrm{H}_{2} \mathrm{O}$ removal efficiency. It can be seen that the elimination performance is significantly lower in R4 than R5 regarding $\mathrm{CO}_{2}$ and $\mathrm{H}_{2} \mathrm{~S}$ elimination. A possible reason for this was that run R5 contained activated carbon, which is extremely porous and thus has a very large surface area for adsorption of $\mathrm{H}_{2} \mathrm{~S}$ and simultaneously $\mathrm{CO}_{2}$. However, runs $\mathrm{R} 4$ and $\mathrm{R} 5$ are able to achieve removal efficiency of $\mathrm{H}_{2} \mathrm{~S}>82 \%$ and $95 \%$ (final $\mathrm{H}_{2} \mathrm{~S}=82 \mathrm{ppm}$ and $20 \mathrm{ppm}$ ) at $10 \mathrm{~g}$. Regarding these conditions the removal efficiency of $\mathrm{CO}_{2}>84 \%$ and $91 \%$ (final $\mathrm{CO}_{2}<6 \%$ and $4 \%$ ) and $\mathrm{H}_{2} \mathrm{O}>95 \%$ and $93 \%$ (final $\mathrm{CO}_{2}<0.2 \%$ and $0.3 \%$ ) for $10 \mathrm{~g}$, respectively.

The study results obtained reveal that the most efficient runs of the treatment process were in order of R $5>\mathrm{R} 1>\mathrm{R} 4$ $>\mathrm{R} 3>\mathrm{R} 2$. Among all results showed that the removing efficiency with the best performance was R5. We also observed that the $\mathrm{Fe}^{\mathrm{o}}$ was more efficient in $\mathrm{R} 2$ than $\mathrm{R} 4$ for removing of $\mathrm{H}_{2} \mathrm{~S}$.

3.6. Comparison of Upgrading Methane Concentration in the Treated Biogas. The concentration of $\mathrm{CH}_{4}$ increased sharply over the investigated period with the increasing mass of substances as well as $\mathrm{pH}$ value in the removal media of $\mathrm{R} 1$ and $\mathrm{R} 3$ while $\mathrm{CH}_{4}$ concentration increased with low $\mathrm{pH}$ and high quantity of reagents for R2 as shown in Figure 6(a). However, the maximum $\mathrm{CH}_{4}$ concentration abilities reach approximately $95 \%, 94 \%$, and $95 \%$ at $10 \mathrm{~g}$ for runs R1, R2, and R3, respectively. Figure 6(b) clearly shows that the $\mathrm{CH}_{4}$ concentration increases favorably with mass of reagents. As far as enrichment of $\mathrm{CH}_{4}$ concentration in the gas phase is concerned, the highest increase was observed with $10 \mathrm{~g}$ removal process, achieved in R4 and R5 (95\% and 96\%), respectively. For the sake of comparison, the best methane concentration in the feed biogas was achieved in $\mathrm{R} 5$ regarding of $\mathrm{CH}_{4} / \mathrm{CO}_{2} / \mathrm{H}_{2} \mathrm{~S} / \mathrm{H}_{2} \mathrm{O}$ mixtures.

The $\mathrm{H}_{2} \mathrm{~S}$ is removed by $\mathrm{Fe}_{2} \mathrm{O}_{3}, \mathrm{Fe}^{\mathrm{o}}$, and $\mathrm{FeCl}_{2}$ through chemical transformation of $\mathrm{H}_{2} \mathrm{~S}$ into $\mathrm{S}$. This chemical method is fascinating as it eliminates the pollutant $\mathrm{H}_{2} \mathrm{~S}$. The activated carbon removes $\mathrm{H}_{2} \mathrm{~S}$ by simple adsorption through its mesoporous surface. The water vapour is removed by physical adsorption only. The experimental results revealed that $\mathrm{CH}_{4}$ 
is possible to enrich by $95 \%$ using the chemical and physical removal process for $\mathrm{CO}_{2}, \mathrm{H}_{2} \mathrm{~S}$, and $\mathrm{H}_{2} \mathrm{O}$. Therefore, these processes are feasible to meet the standard for injection of the gas in grid or vehicle fuel [26].

\section{Conclusions}

We generated biogas from the wastes of cafeteria, vegetable, food, and cattle manure. The source of material used in biogas production has a significant effect on the composition of biogas. The results showed that the $\mathrm{CaO}$ solutions are capable of reducing $\mathrm{CO}_{2}$ concentration below 6\%. Removal of $\mathrm{H}_{2} \mathrm{~S}$ was investigated by treating the raw biogas with $\mathrm{FeCl}_{2}$, $\mathrm{Fe}^{\mathrm{O}}, \mathrm{Fe}_{2} \mathrm{O}_{3}$, and activated carbon. Approximately the $\mathrm{H}_{2} \mathrm{~S}$ concentration was reduced to $89 \%, 90 \%, 86 \%, 85 \%$, and $96 \%$ for treating the raw biogas with $\mathrm{pH}$ for $10 \mathrm{~g}$ of $\mathrm{Fe}_{2} \mathrm{O}_{3}, \mathrm{Fe}^{\mathrm{O}}$ $\mathrm{FeCl}_{2}$, and without $\mathrm{pH}$ for $\mathrm{Fe}^{\mathrm{o}}$, and activated carbon for $\mathrm{R} 1, \mathrm{R} 2, \mathrm{R} 3, \mathrm{R} 4$, and $\mathrm{R} 5$, respectively. Removal of $\mathrm{H}_{2} \mathrm{O}$ was investigated by treating the raw biogas with $\mathrm{Na}_{2} \mathrm{SO}_{4}$ and silica gel. The $\mathrm{H}_{2} \mathrm{O}$ concentration was reduced to $0.2 \%, 0.7 \%$, $0.2 \%, 0.2 \%$, and $0.3 \%$ for treating the raw biogas with $10 \mathrm{~g}$ of $\mathrm{Na}_{2} \mathrm{SO}_{4}$ and silica gel, for R1, R2, R3, R4, and R5, respectively. The conclusions are also confirmed in regard to performance run $\mathrm{R} 5$ which is the best purification process. The possibility for the enrichment of above 95\% in biogas using combined chemical absorption and adsorption indicates the practical application of this process.

\section{Competing Interests}

The authors declare that they have no competing interests.

\section{Acknowledgments}

The first author would like to acknowledge the Ministry of Education, Culture, Sports, Science and Technology (Monbukagakusho: MEXT) for providing the financial support (Ph.D. scholarship) for this research and the extended help of thermal engineering laboratory under the Department of Mechanical System Engineering, Kumamoto University, Japan, for providing the facility for experimentation. They thank their biomass group lab mates for helping with the measurements.

\section{References}

[1] M. R. A. Mamun, M. S. Kabir, M. M. Alam, and M. M. Islam, "Utilization pattern of biomass for rural energy supply in Bangladesh," International Journal of Sustainable Crop Production, vol. 4, no. 1, pp. 62-71, 2009.

[2] C. N. Hamelinck, G. Van Hooijdonk, and A. P. C. Faaij, "Ethanol from lignocellulosic biomass: techno-economic performance in short-, middle- and long-term," Biomass and Bioenergy, vol. 28, no. 4, pp. 384-410, 2005.

[3] Y. Sun and J. Cheng, "Hydrolysis of lignocellulosic materials for ethanol production: a review," Bioresource Technology, vol. 83, no. 1, pp. 1-11, 2002.

[4] M. Pöschl, S. Ward, and P. Owende, "Evaluation of energy efficiency of various biogas production and utilization pathways," Applied Energy, vol. 87, no. 11, pp. 3305-3321, 2010.
[5] F. Rossi and A. Nicolini, "A cylindrical small size molten carbonate fuel cell: experimental investigation on materials and improving performance solutions," Fuel Cells, vol. 9, no. 2, pp. 170-177, 2009.

[6] F. Cotana, F. Rossi, and A. Nicolini, "A new geometry high performance small power MCFC," Journal of Fuel Cell Science and Technology, vol. 1, no. 1, pp. 25-29, 2004.

[7] F. Rossi and A. Nicolini, "Ethanol reforming for supplying molten carbonate fuel cells," International Journal of Low-Carbon Technologies, vol. 8, no. 2, pp. 140-145, 2013.

[8] J. Chang, J. Fontenelle, and N. Serveau, "Inventaires des émissions polluantes atmosphériques en France, séries sectorielles et analyses et étendues," Tech. Rep., CITEPA, Paris, France, 2007.

[9] A. Wellinger and A. Lindberg, "Biogas upgrading and utilisation," IEA Bioenergy Task 24: Energy from Biological Conversion of Organic Waste, 2005.

[10] E. Wheless and J. Pierce, "Siloxanes in landfill and digester gas update," Whittier (Canada) and Long Beach (California): Los Angeles Country Sanitation Districts and SCS Energy, 2004.

[11] M. Hagen, E. Polman, J. Jensen, A. Myken, O. Jönsson, and A. Dahl, "Adding gas from biomass to the gas grid," Report SCG 118, Swedish Gas Center, Malmö, Sweden, 2001.

[12] M. Persson and A. Wellinger, "Biogas upgrading to vehicle fuel standards and grid injection," Report, IEA Bioenergy, 2006.

[13] K. Krich, A. Augenstein, J. Batmale, J. Benemann, B. Rutledge, and D. Salour, "Upgrading dairy biogas to biomethane and other fuels," in Biomethane from Dairy Waste-A Sourcebook for the Production and Use of Renewable Natural Gas in California, K. Andrews, Ed., pp. 47-69, Clear Concepts, California, Calif, USA, 2005.

[14] T. Bansal, N. Tripathi, and G. Chawla, "Upgradation of biogas using combined method of alkaline water scrubbing and adsoption through carbon molecular sieve," International Journal of ChemTech Research, vol. 5, no. 2, pp. 886-890, 2013.

[15] E. Ryckebosch, M. Drouillon, and H. Vervaeren, “Techniques for transformation of biogas to biomethane," Biomass and Bioenergy, vol. 35, no. 5, pp. 1633-1645, 2011.

[16] P. Börjesson and B. Mattiasson, "Biogas as a resource-efficient vehicle fuel," Trends in Biotechnology, vol. 26, no. 1, pp. 7-13, 2008.

[17] N. Tippayawong, A. Promwungkwa, and P. Rerkkriangkrai, "Long-term operation of a small biogas/diesel dual-fuel engine for on-farm electricity generation," Biosystems Engineering, vol. 98, no. 1, pp. 26-32, 2007.

[18] N. Tippayawong, A. Promwungkwa, and P. Rerkkriangkrai, "Durability of a small agricultural engine on biogas/diesel dual fuel operation," Iranian Journal of Science and Technology, Transaction B: Engineering, vol. 34, no. 2, pp. 167-177, 2010.

[19] P. V. Danckwerts, Gas-Liquid Reactions, McGraw-Hill Book Company, New York, NY, USA, 1970.

[20] X.-Q. Li, D. G. Brown, and W.-X. Zhang, "Stabilization of biosolids with nanoscale zero-valent iron (nZVI)," Journal of Nanoparticle Research, vol. 9, no. 2, pp. 233-243, 2007.

[21] W. Yan, A. A. Herzing, C. J. Kiely, and W.-X. Zhang, "Nanoscale zero-valent iron (nZVI): aspects of the core-shell structure and reactions with inorganic species in water," Journal of Contaminant Hydrology, vol. 118, no. 3-4, pp. 96-104, 2010.

[22] A. H. Nielsen, P. Lens, J. Vollertsen, and T. Hvitved-Jacobsen, "Sulfide-iron interactions in domestic wastewater from a gravity sewer," Water Research, vol. 39, no. 12, pp. 2747-2755, 2005. 
[23] D. Rickard and G. W. Luther III, "Chemistry of iron sulfides," Chemical Reviews, vol. 107, no. 2, pp. 514-562, 2007.

[24] M. S. Horikawa, F. Rossi, M. L. Gimenes, C. M. M. Costa, and M. G. C. Da Silva, "Chemical absorption of $\mathrm{H}_{2} \mathrm{~S}$ for biogas purification," Brazilian Journal of Chemical Engineering, vol. 21, no. 3, pp. 415-422, 2004.

[25] R. Weast and I. Hodgeman, Handbook of Chemistry and Physics, CRC Publishing, Boca Raton, Fla, USA, 1958.

[26] M. Persson, "Utvä rdering av uppgraderingstekniker för biogas," Rapport SGC 142, Svenskt Gastekniskt Center, Malmö, Sweden, 2003. 


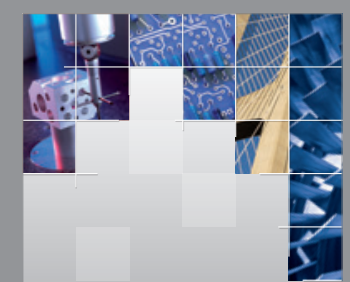

\section{Enfincering}
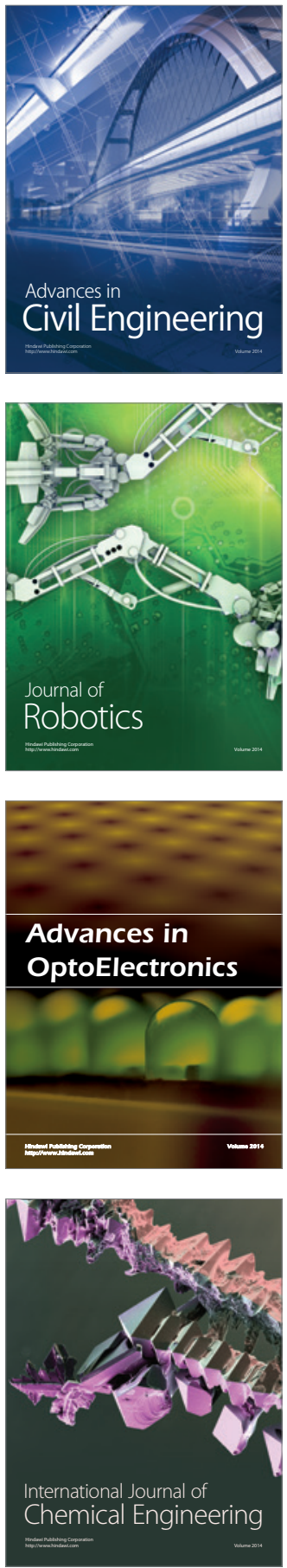

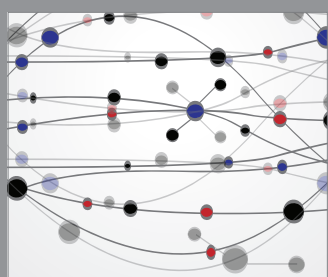

The Scientific World Journal

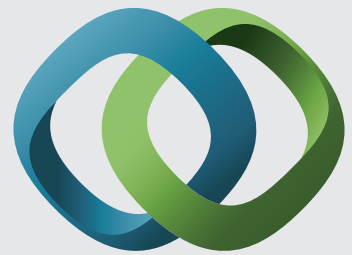

\section{Hindawi}

Submit your manuscripts at

https://www.hindawi.com
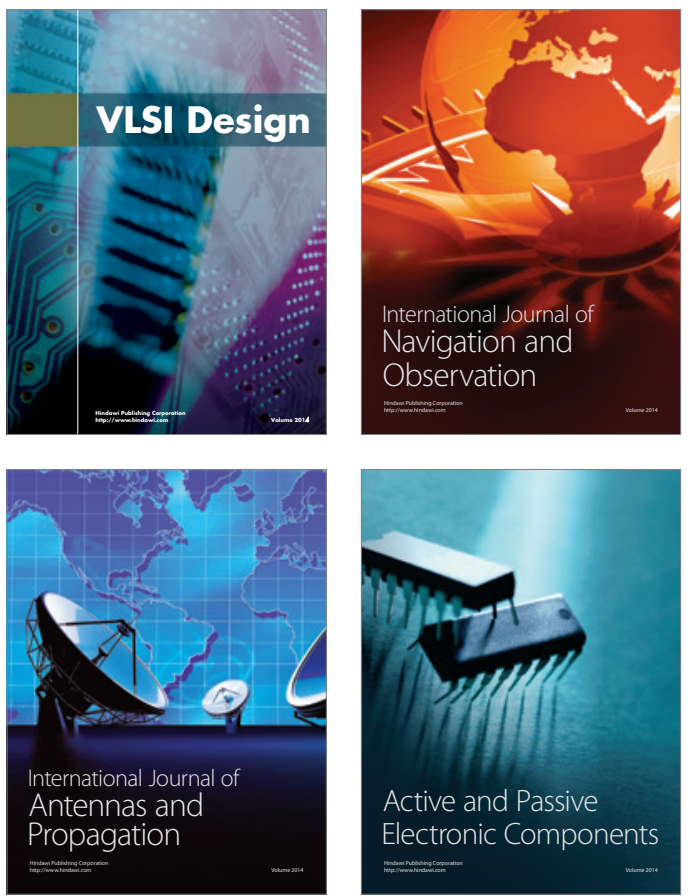
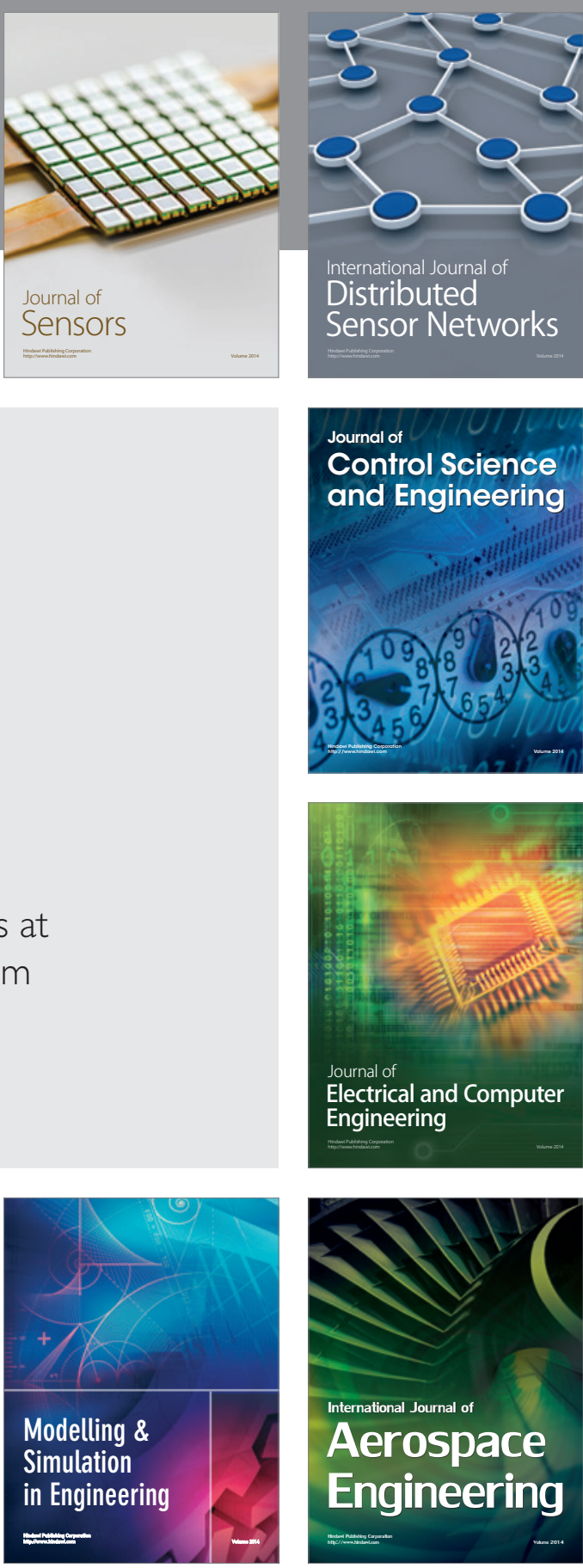

International Journal of

Distributed

Sensor Networks

$-$

Joumal of

Control Science

and Engineering
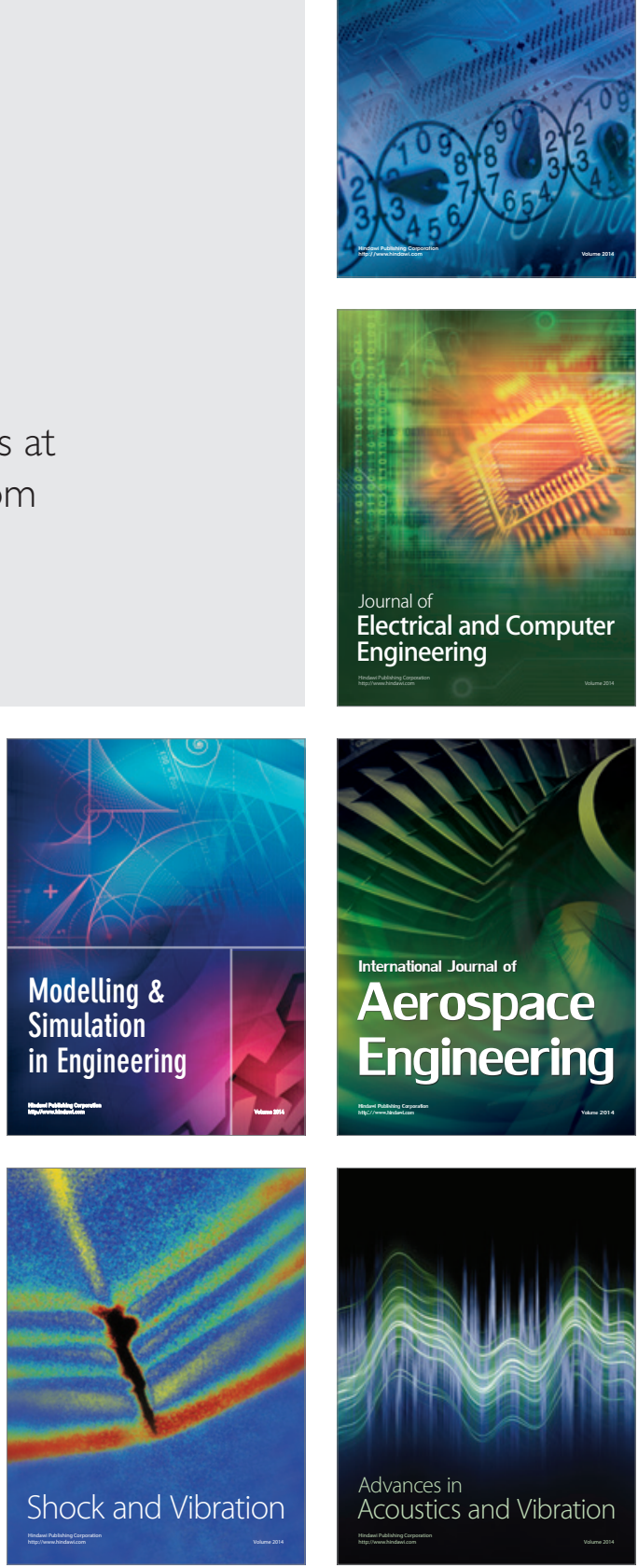